\title{
SEVERING THE BONDS OF LOVE: A CASE STUDY IN SOUL LOSS
}

\author{
MARy Margaret SteEdly \\ Department of Anthropology, University of Michigan, 1054 LSA Building, \\ Ann Arbor, MI 48109, U.S.A.
}

\begin{abstract}
Karo Batak ceremonial curing practices in urban Indonesia take place in a disputed zone of acts and meanings, in which neither social nor cultural coherence can be presumed by the analyst. Examining the therapeutic efforts of an urban Karo spirit possession cult aimed at curing the soul loss suffered by a young man, the Christian son of one of the cult's premier spirit mediums, this paper questions the relevance of the 'integrative model' in such cases, and suggests an alternative approach, looking at the sets of social, cultural and interpersonal tensions that run through the cult's practices and which, at the same time, those practices seek to contain.
\end{abstract}

Key words-Karo Batak, Indonesia, spirit possession, sorcery, urban curing practices, religious pluralism

Anthropological analyses of traditional curing systems have tended to stress the integrative function of the cure. The analytical focus may be directed primarily toward the personal (psychic) [1-3], the social $[4,5]$, or the cognitive [6-8] level. In a general sense, all these analyses address the articulation of the three levels: that is, the integration of personal experience (illness, misfortune) with social values and realities through the vehicle of a 'cultural idiom' [9] of illness, and the use of this explanatory system to mobilize social resources in order to reintegrate the patient into the social world and thus to reconstitute the threatened web of social relations. The efficacy of the cure then lies, according to this view, in its ability to restore coherence to the system, both for the individual and for the society as a whole.

Whether or not this approach can be accepted as generally valid for traditional societies (and whether such an analytical artifact as a 'traditional society' indeed exists), it is evident that in more complex social environments-multiethnic urban settings, societies undergoing the process of fragmentation often described as 'modernization', class-stratified societies, and so forth-there can be no such a priori assumptions of the therapeutic value, or even the existence, of such social and cultural coherence. Fven where-as is frequently the case-the analyst focuses on a smaller unit within the culture, such as a single ethnic group or enclave, a particular religious sect, even a single family group, there is in fact no guarantee of cognitive homogeneity or social unity within the group. For these groups-and their component members-exist within, and in particular relation to, larger fields of discourse and power, in a world of other voices resonating in, and often against, a dominant discourse, as well as with or against one another.

This world is characterized by the fragmentation of the organic unity and coherence of social life in all its aspects. This fragmentation, as Fredric Jameson describes it, utilizing the Lukacsian concept of reification and the related Weberian term rationalization, is a complex process through which the traditional or "natural" .. unities, social forms, human relations, cultural events, even religious systems, are systematically broken up in order to be reconstructed more efficiently, in the form of new post-natural processes or mechanisms; but in which, at the same time, these now isolated broken bits and pieces of the older unities acquire a certain autonomy of their own, a semi-autonomous coherence ... [10].

Recombined and relocated in new, rationalized fields of discourse, these 'semi-autonomous objects' take on a kind of life of their own, in which they address, as well as collide with, one another. In such a context, the therapeutic act may oppose or repudiate the larger discursive fields which it confronts, or it may reproduce them, or it may seek to establish a space of its own not contained within them, but it cannot, any more than any other act can, fail to recognize and respond to their presence. In these circumstances there is always a dis-ease enfolded within the heart of the cure.

What, then, is the nature of the therapeutic act in such circumstances? To answer this question I would return to the 'integrative model' described above, and, rather than taking it for granted, allow the practice of curing to call it into question. Does the cure here attempt to produce at least the preconditions for its integrative function? Does it simply reproduce the (imagined or real) integrative practices of the past as forms of nostalgia, against the fragmentation of the cultural present? Does it generate a new idiom which reproduces the present in 'mythic' [11] form-in, one might say, a cultural idiom of fragmentation? Or is integration no longer even an issue in this fragmented landscape? There is, of course, no single, universal answer to any of these questions. Each curing system, each curing act, establishes its own therapeutic locus within the shifting nets of discourse and power.

With these reflections in mind, it is my intention to examine in this essay one such curing act, performed by members of a Karo Batak spirit possession cult in the city of Medan, North Sumatra, to locate and call back the lost soul of a young man, the Christian son 
of one of the cult's premier spirit mediums. For the participants in this ritual performance, the cure does not take place within a framework of harmonious social relations and cultural understandings, but in a disputed zone of acts and meanings that are themselves embedded in larger frames. The cure here runs aslant to-though not in opposition to-the dominant voice of social discourse. In this setting, the cure takes place not as an attempt-successful or otherwise-to reintegrate the old, shattered social and cultural unities, but rather as a series of nested 'strategies of containment' (to use Jameson's term) not entirely of the participants' making, aimed at breaking apart the totality of social experience into a collection of manageable, autonomous units. The cure here is not an act of restitution or reintegration, but one of deflected resistance, aimed at salvaging meaning and value from the clash of an imagined 'tradition' with the dual, harmonious (and equally imaginary) voices of 'modernity' and 'religion'.

\section{ETHNOGRAPHIC BACKGROUND}

The Karo are one of the linguistically and culturally related peoples of highland North Sumatra generically classed as 'Batak'. The Karo homeland, at the northern end of the Batak region, is located about $60 \mathrm{~km}$ from the present metropolitan area of Medan. On this high, cool plateau, the traditional Karo economy was based upon subsistence dry-rice agricultural production, supplemented by sporadic trading with the Malay kingdoms of the Sumatran east coast. After the Dutch annexation of Karoland in 1904, the Karo began growing European vegetables and fruit for export to the plantation region and expanding urban centers of the coastal lowlands, as well as for shipment to the Malay Peninsula. Today the Karo highlands are one of Indonesia's major vegetable-producing regions.

In the early 1950s, after the conclusion of the Indonesian revolution, many highland Karo began to migrate to the coastal lowlands in search of available farmland. These migrants took over large portions of the formerly European-owned tobacco estates on the outskirts of the city of Medan. Karo settlement in the 50 s was centered on the Padang Bulan Estate on the southwest margin of the city. This area is still known as the Karo district of the city.

Medan, with a current population of approx. 1.5 million [12], is the capital of the province of North Sumatra and one of Indonesia's largest cities. This rapidly expanding metropolitan area has now absorbed the previously rural Padang Bulan district. Thus Karo who originally moved to the lowlands in search of new agricultural land as well as new economic opportunities now find themselves, willy nilly, city dwellers.

Urban Karo fall roughly into three occupational groups. First are the petty entrepreneurs: traders and produce brokers. shopkeepers, and towkay motorowners of commercial transport vehicles. The second group is composed of better-educated Karo, who tend to gravitate to the professions: law, medicine or education, rather than to business or office work. The third group, rather a residual category, is made up of young men who have neither the education to enter a profession nor the capital (nor, perhaps, the inclination) to go into entrepreneurial activity. They may work as bus drivers or conductors, but more frequently spend their time idling in the coffee shops, or else enter the quasi-underworld of the preman (Dutch vrij man, freeman, civilian)-casual day laborers and petty criminals who serve as informal 'security' guards in the markets and bus stations, Aside from these young men, most urban Karo men and women are involved in some sort of economic activity. Small-scale trade is mostly in women's hands, and whatever economic endeavors they, or their husbands, engage in, most women also maintain some farmland for growing the family's rice.

Despite the rapid transformation of the economic and political bases of Karo society, it is apparent that, as Kipp has noted, "the foundation of Karo life. the kinship system, remains firmly intact" [13]. Like the other Batak groups, the Karo are distinguished by a form of social organization based on patrilineal descent reckoning and preferential matrilateral crosscousin marriage. Karo society is divided into five major exogamous clans, and all clan-mates regard one another - at least metaphorically - as agnates. It is this system of kinship that orders every aspect of Karo social life.

Virtually every social relationship, even a chance encounter between strangers at the market, is conducted according to the principles of kinship. The primary forms of kin relations are the ties of equality and mutual support between clan-mates (senina, same sex sibling), and the asymmetrical relations between superior wife-giving groups (kalimbubu) and their subordinate wife-receivers (anak beru). The (kalimbubu-anak beru relationship is marked not only by a status differential in which the kalimbubu wifegivers are considered as the 'visible god' (dibata niidah) of their anak beru, but also by numerous reciprocal rights and obligations between the two [14].

Ritual serves as the principal public arena for the enactment and articulation of these kin relations, and the giving of well-organized and well-attended rituals is both an indicator of kin-group solidarity and a significant marker of social status. Kin relations are symbolically acted out in all aspects of ritual, from the dancing of the kin groups that opens the ceremony and the seating arrangements that mark kin group roles and statuses, to the transfer of objects which serve as representations of the ties between kin. The presence of members of the various kin groups of the rituals' sponsor is required, and each group has a specific role to play in the ritual. In practical terms, the most significant role is that of the anak beru wife-receivers, who perform all the necessary labor, cook and serve the food, distribute gifts to the guests, and serve as mediators in ritual negotiations. Without the labor provided by the anak beru, the sponsorship of a successful ritual is impossible. The kalimbubu (by birth and by marriage) of the sponsor must also attend the ritual to bestow their blessings and to legitimize the proceedings. The sponsor's own family and clan-mates should likewise be present as a sign of group unity. Should any of these kin groups not participate, the ritual would not only fail as a representation of the ideal of kin-group harmony, it would 
literally fail and the sponsor might expect dangerous spiritual repercussions [15].

The Karo see their social life as retaining its coherence in the face of the challenges of 'modernity' through their continued adherence to their distinctive adat (tradition, customary law) and the kinship system upon which it is based. In this assertion, the Karo are in agreement with generally held anthropological views of contemporary Batak society [16]. As one anthropologist has described the relationship between tradition and modernity in Batak societies, adat and its ritual expressions, creatively adapted to new circumstances, have "served recent generations of villagers and townsmen as a sort of cultural gyroscope allowing them to keep their balance in their society's truly headlong rush into modernity" [17]. While this description is accurate enough, matters are not, for the Karo at least, as simple as this might suggest. Adat and kinship do indeed provide coherence to urban Karo life, but they also comprise a 'combat zone' in which a struggle for ideological existence is being waged.

\section{ADAT AND RELIGIOUS PLURALISM}

Karo society today is religiously pluralistic. The majority of urban Karo are Christian Protestants, although there are significant numbers of Muslims and Roman Catholics as well [18]. The traditional Karo veneration of ancestral and territorial spiritsnow known among its followers as agama Pemena, the 'original religion'- -also remains alive in the city, though its influence appears stronger in rural areas. Karo stress the religious tolerance of their community, pointing to extended kin networks, even nuclear families, which contain Protestants, Catholics, Muslims, and followers of Pemena, all living in apparent harmony and understanding. It is their common adherence to adat, they say, that allows them to transcend religious factionalism. This is indeed true, but only in a limited sense which obscures the nature of the ongoing religious struggle over the definition of adat.

Christian Protestants are clearly the dominant group in Karo society, especially in the city. The most significant Protestant denomination is the GBKP (Gereja Batak Karo Protestan), the Karo Protestant Church. The GBKP is the self-proclaimed voice of the educated, 'progressive' element of Karo society, and also the equally self-proclaimed protector of Karo language and cultural identity-and thus also the voice of adat. The GBKP, through a series of seminars and publications, has endeavored to redefine adat in a way acceptable to all Karo. Adat, according to this view, consists of those aspects of Karo custom that are universally accepted by all Karo, with regional variation eliminated and with what is described as kinitekan - 'belief'-purged [19]. In this new, rationalized form, adat has become a set of secularized rules for appropriate behavior between kinspeople, detached from its former supernatural context and imbued instead with the new moral justification of social responsibility.

Since 'belief' is now considered-at least by Christians-as external to adat, rituals become, by definition, secular events. This also means that only those rituals which can be secularized are now considered a part of adat. Weddings, funerals, and house openings are the key rituals of this new secular adat, while rites of spirit propitiation, seances for the souls of the dead, and spirit possession ceremonies-all the ceremonial expressions of agama Pemena-are no longer adat rituals at all, but rather rituals of 'belief'. Thus, the argument goes, Christians are no longer required, under adat, to participate in rituals of spirit worship sponsored by their kin, any more than they would require their 'pagan' kin to attend Christian worship services. This is the essence of religious tolerance. Yet Christian faith is an individual matter and rites of spirit propitiation are communal in nature, and this makes a significant difference in the believer's ability to carry out the precepts of his or her faith. If one's Christian anak beru fail to provide the necessary labor, or if one's Christian kalimbubu refuse to bestow their blessing, how can a ritual-even a ritual of 'belief'-be undertaken?

Though the followers of agama Pemena do not totally accept this secularized vision of adat, it hasbecause of the social and cultural dominance of the educated, more affluent Christian community-had a significant impact on their traditional religious practices. Community-based rites of propitiation and supplication of the spirits have almost entirely ceased to be performed on account of Christians' refusal to take part. Even smaller family ceremonies which, like all Karo ritual, stress the participation of members of quite extended kin groups, are often difficult to sponsor as a result of religious differences between kin. Stripped of most of its public and communal aspects, what remains of agama Pemena todayespecially in the cities-is essentially a privatized cult of healing. based on individual relationships with powerful, benevolent superhuman beings called keramat that serve as spirit guides of possessed mediums, bestowing good fortune and the ability to cure upon their human hosts [22].

Christians have, as might be expected, a different view of these, and other spirits. They consider the spirit beliefs of the followers of agama Pemena as 'old-fashioned', unscientific and not in keeping with the image of respectable modernity that they wish to present. They do not, however, deny the existence of spirits; indeed, most Christians are quite convinced of their reality and their power. What they do question is the moral basis of human-spirit interactions. As Christians, they feel that they should have nothing to do with these supernatural beings, which they consider as either dangerously amoral or as purely evil [21]. Christians tend to associate traditional forms of spirit worship with 'satanism', and to suspect those who take part in these rites of being evil sorcerers who utilize the 'powers of darkness' for avaricious and vengeful ends. Thus, the general assertion of religious tolerance should not be taken entirely at face value, for beneath this superficial agreement to 'live and let live' there is a deeper ideological antagonism between religious groups which has, in the past (though not, apparently, today), led to physical confrontation and even occasional violence.

This antagonism between Christian Karo and followers of agama Pemena is exacerbated by the religious policy of the Indonesian government. The 
pancasila, the 'five principles' upon which the Indonesian state is ideologically based, enjoins all citizens to 'believe in One God'. All Indonesians should be members of some officially sanctioned, 'monotheistic' religion. Though this technically means that all are free to belong to the religion of their choice, the options as to what counts as a religion are somewhat limited: Islam, Protestantism, Catholicism and-with a bit of stretching of the concept of monotheismHinduism and Buddhism. What rather pointedly do not fall under the rubric of religion are the various local systems of spirit veneration such as agama Pemena, which have neither a 'book', a 'church', nor a bureaucratic organization [22].

In this situation, many followers of agama Pemena have affiliated themselves with the provincial chapter of a pan-Indonesian Hindu reformist organization, Parisada Hindu Dharma. Agama Pemena has thus become, for official purposes at least, the Karo branch of the government-approved Hindu religion. This official affiliation has provided a legitimacy to agama Pemena that protects its adherents from the more extreme aspects of social and political discrimination. It has, however, had little, if any, effect on the nature of Karo religious beliefs and practices, which bear only the most superficial resemblance to the great religious tradition of Hinduism, in either its Indian or its Balinese manifestation [23].

Karo 'Hinduism' has, however, provided a degree of organizational support for some of its new followers. One group which has formed under the auspices of Hindu/Pemena is the 'Arisan' (a kind of revolving credit association) of the neighborhood of Simpang Meriah [24]. This organization, with a current active membership of about 25 families, was ostensibly begun as a Hindu study group, but its main purpose has been to provide financial and participatory support for the ritual activities-in particular, spirit possession ceremonies-of its members.

Arisan-sponsored spirit possession ceremonies are most often held in response to some misfortune, often illness. That was the case with the ceremony I will describe below. While the account that follows cannot attempt to reproduce the full complexity of ritual action, I hope that some of the richness, ambiguity, humor and seriousness of this performance remains, and that the reader, too, can experience a bit of the struggle which-in the face of human suffering, fragmented lives and unattainable ideals-defines the Arisan's therapeutic endeavor.

\section{INSIDE THE ARISAN}

The Arisan was formed approx. 7 years ago, around a core group of female spirit mediums [25]. The organization's main social function is a monthly possession ceremony sponsored by one of its members on a rotating basis. This is usually led by one or more of the Arisan's senior mediums. All members are expected to contribute a small amount of money and rice each month to the group's treasury. Each member may use these to help finance the ceremony that he or she sponsors. The Arisan also owns a large set of plates and glasses that may be rented by members for a nominal fee. It is expected that members will attend each other's ceremonies and help with the work-cooking, cleaning, preparation of offerings and the like-tasks that would, in the past, have bcen the responsibility of the sponsor's wife-receiving anak beru. Several male Arisan members are musicians, and they perform at Arisan ceremonies for a nominal fee, as do the mediums who officiate at these ceremonies.

The social and economic support of the Arisan is essential to many of its members if they are to sponsor spirit-possession ceremonies. Most Arisan members are small-scale market traders or produce brokers whose incomes are both low and uncertain. Without the Arisan's aid it would be difficult for them to save enough money to sponsor such a ceremony, which can be a rather expensive undertaking. In addition, since many members' Christian or Muslim kin refuse to take part in what they consider heathen, even 'satanic', rituals, the labor provided by fellow Arisan members is critical to ceremonial sponsorship.

The Arisan has another important function for its members as well: it serves as the locus for the informal education and training of its members. Except for the most senior mediums and a few elderly women who act as their ritual assistants, most Arisan members have only recently become involved in spirit possession activities. By attending the ceremonies of other members, by observing and talking to experienced mediums, and by taking part in group trance activities, these novice ritual participants begin to learn how to perform in a cermonial context.

Recruitment of new members to the Arisan has largely taken places among patients and former patients of the senior spirit mediums. Illness is indeed the initial sign of the potential medium's vocation, an indication that there is a spirit (or, more frequently, spirits) that wishes to 'follow' this new host. If the afflicting spirit is one of the benevolent keramats, the relationship between spirit and host may be formalized through the performance of an initiation ceremony. At this ceremony, the host is possessed by her new spirit guides, who give their names, their place of origin and the offerings that they will require in the future. Not all these spirits bestow the ability to cure upon their hosts, but most of the Arisan mediums will lay claim to at least one such curing spirit.

By initiating new members as potential mediums and spirit hosts, the senior mediums are able to gain a following within the organization. Such a following is a demonstration of the medium's success and expertise. A large following serves to enhance the medium's prestige within the group as much as does the display of the material benefits of mediumship fine clothes, educated children, a new house, the ability to sponsor lavish ceremonies. Yet success has its own hazards, and the senior mediums are not only the paragons that their followers wish to emulate, but also the targets of gossip, envy and barely disguised sorcery accusation. Not surprisingly, the sources of much of this suspicion and resentment are the other senior mediums. These mediums are, after all, not only fellow members of the Arisan, they are also commercial rivals. For them, Arisan ceremonies are an arena for the demonstration of their skills and success-a form of reputation-building with real, material benefits as its goal. 
Mediumship is, for the Arisan's senior mediums, a lucrative profession. Their patients are not only drawn from within the group itself, but also from the Christian Karo community and even, in the case of the more well-known mediums, from other ethnic groups. Sorcery is the near-universal diagnosis offered by the mediums of the Arisan to their patients, and it is clearly the diagnosis that most patients expect to hear from the medium. While the medium will rarely name the person responsible for a sorcery attack, patients usually have a candidate in mind. This person might be a neighbor, a business associate or competitor, a spurned lover, or, frequently, a close affinal kinsperson. Whoever the suspected sorcerer might be, the reasons the victim puts forth for the suspected attack are inevitably the same: a hidden envy or resentment of the victim's success, an unnatural competitiveness that contradicts the social ties (whether these be ties of kinship, class or simple friendship) that should exist between persons. These are the same reasons that the Arisan members give for suspecting one another of sorcery.

In the eyes of the dominant Christian community, the Arisan is not only an embarrassing reminder of the 'pagan' past, but also a nest of devil-worshiping sorcerers. What is perhaps equally bad-or perhaps only the same thing in other words-is that, in the view of Christians and nonChristians alike, all contemporary curers (and this certainly includes, but is not limited to, the Arisan members) are komersil, 'commercial': they have forgotten the true compassion that should inhere in their calling and instead are interested only in making as much money as possible from their patients. The Arisan members, of course, see things somewhat differently, and they couch their position in moral terms that could have been borrowed from Christianity or Islam.

The Arisan mediums envision an absolute moral opposition between sorcery and their own curing practices. It is the establishment of a permanent host relationship with certain powerful and benevolent spirits, known as keramat, that, in the Arisan's view, gives one the ability to cure and to act as a medium. These keramat spirits impose exacting standards of behavior upon their hosts; if these are not met, the keramat may either desert or punish the host for this breach. The spirit's first demand is that the host be 'clean'. This means that the host may not serve as the vehicle for impure spirits-a category which includes both the evil spirit familiars of the sorcerer and those spirits of the dead who have died an unclean death (e.g. through sickness). The medium may have to follow certain dietary restrictions, frequently against eating pork, and may not raise pigs. But the keramat's primary requirement is that its powers not be used by the medium for personal gain or to injure others. The Arisan members say that keramat spirits are 'good' and compassionate; their only wish is to help those in need [26]. The medium may cure, with the spirits' help, but only to 'gain mothers and fathers', that is, to establish new kin-like ties of mutual support and obligation with patients. If the medium cures out of a feeling of compassion, the spirits will, in due time, reward this selflessness by providing blessings and prosperity-for which the medium must, in turn, reciprocate in the form of offerings and ceremonial entertainments. Still, success is essential and the mediums frequently complain of the stinginess and lack of understanding of their patients who, having been cured, do not sufficiently reward them for their efforts.

For the Arisan's mediums, the dilemma of success is located here. A medium's success, visible in the material benefits that the spirits indirectly bestow, serves as a sign of the spirits' continued support and thus as a proof that the medium is acting in accord with the moral precepts of the keramat spirits. Yet a medium's success may also be interpreted as a sign of her abuse of the spirits' authority or, worse, of her utilizing, not the beneficent guidance of the keramat, but rather the dark powers of sorcery. From the point of view of the successful medium, this dilemma is reversed: the medium, whose success is attained through adherence to the keramat's moral directives and through her own compassion, becomes a potential victim of the machinations of envious others, of the sorcerers who resent the successful. It is thus along the webs of sorcery as much as through the keramat's moral bonds that the Arisan's social relations run.

Yet suspicions of sorcery within the Arisan generally remain enclosed in the sphere of ceremony (though hints do also emerge in members' gossip), where they can be enacted through the mediation of possessing spirits. To state publicly these suspicions would be to affirm the dominant view of the Arisan as a nest of sorcerers and to cast doubt upon the moral basis of the mediums' practice. Though the Arisan members know that within the group there are those whose skill and success derive not from the benevolence of the 'clean', moral keramat spirits but from the corrupt and destructive powers of sorcery, it is the fiction that this is not so that holds the Arisan together.

\section{NANDE HARTA'S CEREMONY}

I first learned that this ceremony would be held-as was often the case-rather coincidentally. I happened to meet one of the Arisan's members, Nande Imah [27], in a roadside cafe one afternoon and, over a bowl of chicken soto, she mentioned that Nande Harta, one of the Arisan's senior spirit mediums, would be sponsoring a ceremony at the next full moon. It would, she hinted, be something special.

Nande Harta and her husband ran a coffeeshop alongside the main road of Padang Bulan. I had been there several times before to talk to her, and I had found her to be a likeable, if sharp-tongued, woman of middle age. She was a quiet, observant person, but straightforward in voicing her opinions. She was not the sort of person to suffer fools gladly, which must have been something of a trial to her family, for her husband, Bapa Harta, tended in the opposite direction, playing the fool whenever possible. Bapa Harta disapproved of the Arisan, ridiculing them and frequently announcing that in his opinion they were just a bunch of sorcerers. As was common among Arisan members, the family was religiously divided. Harta, their eldest son, was a Muslim, but the other four children were, at least nominally, Christian. 
Bapa and Nande Harta were, of course, followers of Hindu/Pemena despite Bapa Harta's frequent criticisms of spirit mediumship.

Nande Harta was one of the Arisan's more influential members, but she rarely attended the ceremonies of other members. She had a variety of excuses for her nonparticipation, but these reasons were not credited by the other members, who criticized her harshly (behind her back) for her lack of groupspiritedness. The truth of her absences appeared to have more to do with her resentment of another of the Arisan's mediums, Nande Jarum, who was by far the wealthiest and most successful member of the group. In turn, it was Nande Jarum whose criticisms of Nande Harta's absences were the most biting.

Nande Jarum was the central figure in the Arisan. Although she was not the most senior of the Arisan's mediums, she had established a large following within the group due to her notable success as a curer. Many of the junior mediums attempted to emulate her distinctive style of trance dancing and admired her fashionable appearance and expensive clothes, if not her high-and-mighty ways. It was well known that she charged large fees for her services, and some of the Arisan members-among them Nande Hartaattributed any misfortune that befell her or her family to the resultant anger of her keramat spirits [28]. Nande Jarum, of course, blamed any such troubles on the sorcerous intentions of other members of the group. She seemed to be the frequent victim of sorcery, and the blame for these attacks tended to fall upon her most successful rivals-two of whom had, in fact, been forced out of the Arisan because of the widespread suspicion that they were responsible for Nande Jarum's woes.

It was appropriate that Nande Harta was the most outspoken of Nande Jarum's critics. As rumor had it, Nande Harta had at one time been as commercially successful a medium as Nande Jarum was, but because she took advantage of her spirits' powers to demand excessive fees from her clients she had subsequently fallen onto hard times. When her eldest son Harta fell ill as a result (it was said) of the spirits' retribution of this misuse of their benevolent powers, Nande Harta turned away from her mercenary ways. Though the family was now as a result financially strapped, their life had improved-until recently, when her second son, Ndapet, began to suffer from a mysterious illness which doctors could not explain. It was this illness of Ndapet's which proved the stimulus for her sponsoring of this ceremony.

\section{NDAPET'S LOST SOUL}

When my co-worker Juara Ginting and I arrive at the family's coffeeshop the night before the planned ceremony, preparations are already underway, and it is evident that, as Nande Imah had said, the ceremony should be something out of the ordinary. There is an excitement and eagerness among the group present that $I$ have never before observed in such circumstances. One reason for the group's enthusiasm is that the main officiant is to be--not, as I had assumed, Nande Harta-Nande Randal, an elderly woman who is the Arisan's most senior spirit medium and the group's spiritual leader.

Nande Randal has been a spirit medium since she was in her teens, nearly 50 years before. She was, in one way or another, the mentor of all the Arisan's mediums. Now, however, although she always attended Arisan-sponsored ceremonies, she rarely took an active part in the proceedings, claiming that her rheumatism prevented her from doing so. The other members seemed not to take her too seriously as a ritual participant. They claimed that the spirits, for one reason or another, had deserted her. She told me privately that she hadn't much interest in participating these days because the other members didn't perform the ceremonies correctly (though it was not, she added, her place to tell them so). Even worse, she said, certain persons within the Arisan - her intention here was Nande Jarum and her husband, Bapa Jempol, one the Arisan's musicianswere 'keeping' evil spirits, from whom they got their curing abilities and from whose assistance their considerable success derived. These two, according to Nande Randal, would use their evil spirits to disrupt the ceremonies and to 'try' the other mediums.

So, with Nande Randal in charge, Nande Harta and her friends are planning, as they put it, to "do it right' this time, according to adat $k u h$, the full traditional manner.

While the Arisan members who are present prepare the offerings to be given to the spirits, and the food for the next day's guests, Ndapet tells us about the circumstances of his illness. $\mathrm{He}$ is at the time of the ceremony (August 1985) approx. 25 years of age, unmarried, and he works as a bus conductor on one of the many long-distance transport lines running through Padang Bulan. Ndapet appears, to the casual observer, to be in relatively good health, but he complains of not being able to work because of recurrent bouts of illness. He describes his symptoms as weakness and lassitude, frequent stomach pains and bloating. and occasional numbness of the extremities, which shifts from place to place. He is, as Nande Harta describes it, "not really sick but not really healthy either." Ndapet has been experiencing these symptoms for approx. 18 months. During this period he has been to five medical doctors, and has been $\mathrm{X}$-rayed four times, but no explanation of his symptoms has been offered. In fact, one doctor stated that Ndapet wasn't ill at all.

Nande Harta then took her son to a spirit medium. The medium was Nande Randal, with whom Nande Harta has a close personal and professional relationship. When Nande Randal asked the spirits to identify the source of Ndapet's problems, the spirit announced that Ndapet was birawenen - that he had experienced a fright, which had caused his soul (tendi) to escape [29]. The tendi was now being held prisoner by a keramat spirit. No further details were given at that time.

Several nights later, Nande Harta dreamed of a particular spot along the road to Lake Toba near the tourist resort of Prapat. She suspected that this dream might be a message from the spirits, and asked Ndapet if he had ever been frightened in that location. Indeed, Ndapet acknowledged, he had. When he was about 15 years of age and still in junior high school, he had been on a bus that nearly ran over the cliff edge on one of the hairpin 'deadman's curves' leading up from the town of Prapat, just as Nande Harta's dream had indicated.

Nande Harta and Nande Randal then conferred over the meaning of this event. Assuming that the dream portrayed the site of Ndapet's soul's flight, they decided to travel to the place on the next auspicious day and give a kahul-the offering of a live white chicken-and other gifts to the spirits of the place in hope that Ndapet's soul would be released [30]. The freeing of the kahul chicken was to be combined with a ceremonial hairwashing-erpangir $k u$ lau-on the shore of Prapat. Then, once they had returned home, a full spirit possession ceremony would be held to enlist the help of the keramat spirits in curing Ndapet and, at the same time, to repay the spirits for their past beneficence.

This is all a rather complex, expensive undertaking. The living quarters behind Nande Harta's coffee shop are 
bustling with activity as clusters of Arisan members busy themselves with the preparation of offerings, cooking, gathering the needed materials for the next day's ceremony, and-typically-gossiping about absent members. Nande Harta takes it upon herself to supervise and comment on all aspects of the preparations. She proudly points out the chickens she has bought for the spirits' meal-one red, one yellow and two white, each for a different sort of spirit-and the beautiful unblemished white cock that will serve as Ndapet's kahul offering to the spirit of Prapat. Noticing that the small packets of red, yellow and black rice that Nande Imah--one of the junior mediums-is preparing are not sufficiently brightly colored, Nande Harta stops to show her the correct way to mix colors. "That's how complicated this Karo adat is," Nande Imah then editorializes, sighing in amazement. Then she asks the group, "Why are we making these rice packets?" "It's adat kuh, full adat," the answer comes back. "But who are they for?" she continues. "For whoever is there," replies Nande Harta impatiently. "So the red one is for the war-chiefs?" "And the "clear', uncolored rice is for the keramat, the ruler," another of the groups puts in. "The black is for the evil ones," concludes Nande Harta. "They're all there. Only the keramat is the chief. The others are just underlings" [31].

Ndapet shows us the offering table, laden with bowls of fruit, flowers, bags of rice, and the showpiece, a tiny stand with two paper flags, one green and one pink, a special welcome for Nande Harta's spirit guides from across the sea. Meanwhile, counting the green coconuts whose liquid is to serve as the spirits' drink, Nande Harta decides that more are needed and orders a young man out to climb a tree and collect more-this at nearly midnight. As she explains, the group going to Prapat will have to leave by $4: 00$ the next morning in order to arrive there at a propitious time, and she has to make sure that everything is in order and on schedule before she departs. Going to the kitchen to check on the food preparation. Nande Harta berates several of the Arisan's younger members, who are doing the cooking, for their laziness and for talking too much. As she leaves the room, the group returns to their complaints about all the work they have to do.

\section{'DOING IT RIGHT'}

The efforts of Nande Harta and Nande Randal to ensure that this ceremony would be done right, according to adat kuh, must be viewed in the light of the Arisan's problematic relation to Karo tradition. The term adat $k u h$, literally translated as 'full' or 'complete' adat, most commonly refers to a largescale ritual attended by members of all the sponsor's kin categories: not only the anak beru, senina, and kalimbubu, but also the kalimbubu's kalimbubu and the anak beru's anak beru. Adat kuh thus denotes a total representation of the sponsor's kin relations within the ritual. It indicates that the ritual's organization will conform to the proper rules of ritual order, as an elaboration of those kinship relations. This is not, however, what Nande Narta meant by the term, for kinship, as we will see, plays only a minor part in the Arisan's ceremonies. She was referring instead to those parts of Karo tradition excluded by secular definitions of adat as kinship: the spirit offerings, the divinatory procedures, the paraphernalia of possession and the ritual objects associated with the various spirits. She was following, as another medium one put it, the adat of the keramats, not the adat of humans.

This insistence that the ritual be performed in the 'correct' adat manner reflects a general concern of Arisan members for the validity of their practices in traditional terms, a validity denied by the secularized adat of kinship. But it also reflects a more immediate concern centering on the misuse of the medium's powers. The completeness and correct performance of the ritual, a sign of the medium's skills, ensures that sorcery attacks do not disrupt the ceremony and possibly harm the other participants. A successful ritual performance also serves as proof of the good will of the keramats, and thus as a guarantee of the sponsor's own good behavior. For Nande Harta, who had once been subject to punishment for her abuse of the powers of the keramats, it was essential that Ndapet's illness not be interpreted by others as another sign of the keramats' disapproval. For Nande Randal, the ceremony was an opportunity to demonstrate her skills and knowledge, and to reassert her authority within the Arisan by proving that she had neither lost her abilities nor the support of the keramats. Perhaps most important, for everyone involved in the effort to 'do it right', it was a chance to show up Nande Jarum, whose own rituals had tended to stress lavishness and ostentatious display over 'correctness' according to adat.

\section{SETTING FREE THE KAHUL OFFERING}

The group that departs for Prapat at dawn for the mulahi kahul ('setling free the live uffering') ceremony consists of 11 people. There are Ndapet, his parents and a younger brother, and two teenage cousins of Ndapet's who are going along to represent his kalimbubu and anak beru. The old medium Nande Randal is to officiate at the ceremony, assisted by one of the Arisan's junior mediums, Nande Sila. Nande Sila is one who has 'double layered vision', si dua lapis matanya-that is, she can see the otherwise invisible world of the spirits, and her task is to watch for the spirits' arrival at the ceremony. The group is filled out by myself, my assistant Juara Ginting, and a friend of Ndapet's who supplied the minibus for the trip.

The trip to Prapat is a bumpy, grinding $3 \mathrm{hr}$ drive, through the flat rubber plantation region of the coastal plain. As the road turns inland, it begins to climb upward through rolling wet-rice fields and, after a final ascent, winds along the edge of the plateau overlooking the startlingly beautiful expanse of Lake Toba and its island center, Samosir. As we approach the town of Prapat and begin the descent to the lake, Nande Harta begins to look for the place she saw in her dream. After a bit of driving around, she selects the spot, at the first of a series of S-curves. Apparently the guard rail along the cliff side is new; this misled her at first, for there had been no such railing in her dream. She calls to the spirits, then says that this is indeed the correct place, that the spirits are here.

Once the site has been selected, the women busy themselves with the preparations for the ceremony, They begin by constructing a triangular bamboo offering table (anjapanjap) on the narrow, grassy margin beyond the guard rail, and decorating the table's rim with a fringe of shredded aren-palm fronds. Another such fringe is attached at one corner pointing towards the road: this fringe waves gently in the breeze. a welcome to approaching spirits. A young aren-frond stands erect at each of the table's corners, and each of the corners are hung with clusters of betel leaves and areca nuts. Atop the offering table is a fine new woven mat covered with a new white cloth (uis dagangen). The various offerings to the spirits are placed on the table. Once this is done, the women prepare the liquid (pangir), made of six varieties of citrus fruit, flower petals, cologne and ground spices mixed with 'clear water', for the ceremonial hairwashing that is to follow the freeing of the kahul chicken. 
The other members of the party take little part in the preparations. Ndapet's female cousin helps a bit with preparing the aren-palm fringe for the table, but quickly bores of the task and goes to sit on the guard-rail and chat with the others while Nande Randal finishes up the work. Ndapet's younger brother is told to light the charcoal in an incense burner, and he does. Ndapet and his male cousin help find rocks to prop up the table's legs, then they also retire to the guard rail to smoke cigarettes. Bapa Harta is nowhere in sight; we learn that he has walked down the road to the nearest coffee shop. Nande Sila confides to me that he has only come along because Nande Harta paid him Rp. 15,000 (about U.S. $\$ 15.00$ ) to do so.

When everything is finished, Nande Randal takes a package of betel leaf quids from the table and checks to make sure that the correct ingredients have been added. Then, holding the bundle of betel leaves in her hand and placing a white cloth over her head, she begins to sing the invocation, asking permission of the spirits to perform the ceremony. She first addresses beraspati nu taneh, the spirit of the earth, then dibata si mula tieng tembe, god the creator, and the various local spirits of Prapat and of the lake, whether they are of human or nonhuman origin. In her song she explains that we have come to seek Ndapet's lost soul, accompanied by his unak beru, kalimbubu and senina. Nande Randal then calls her own personal heiping spirits from the mountains of Karoland. These spirits are to act as mediators in the negotiations with the Prapat spirits for the return of Ndapet's soul.

While Nande Randal is singing the invocation, Nande Harta prepares the chicken by smoking it in the fumes of incense from the charcoal burner. Placing a white cloth over Ndapet's head, she hands him the fine white cock and orders him to join Nande Randal in front of the offering table. Abashed, he does as he is told, clutching the chicken's feet nervously until the women, amused, tell him to hold the chicken right side up, "so it will look nice"

After continuing the invocation for about a quarter of an hour, Nande Randal begins to be possessed by her spirit helpers, one after the other. Finally. Nande Sila announces that the soul is visible in the distance, accompanied by a pretty young girl with long hair.

Once the soul has arrived, Nande Randal takes the chicken from Ndapet and sets it free beneath the offering table. Ndapet is then toid to choose one of the packets of colored rice that Nande Harta had been so particular about the night before; he chooses the most auspicious one, the 'clear', uncolored rice belonging to the keramat spirits.

This part of the ceremony is now completed. The mat and white cloth on the offering table are removed to be taken home, but the rest of the offerings-and the white cock, wandering about beneath the table searching for scattered grains of rice-are left behind for the spirits.

For the hairwashing, the entire group drives down to the public beach at Prapat. There, amid the tourists and paddle boats, each of us takes a bowlful of the prepared liquid and rubs it, thick with citrus pulp and peelings and with pink and white flower petals, in our hair and over our bodies. We then bathe in the lake, Nande Randal and Nande Sila swimming about, enjoying a playful moment. Even Ndapet's two cousins, who have been up to this time as blase as only well-dressed urban teenagers can be, join in the fun. Then, once we are all done with our swims and dressed again in dry clothes, still picking flower petals out of our hair and joking about how odd we must look to the tourists and paddleboaters, we gather to eat together on the shore in a picnic atmosphere.

Ndapet is given a traditional Toba-Batak cloth as an upah tendi, a 'soul's reward' intended to encourage his soul to remain 'calmly at home'. He wears it draped over his shoulder and strokes it from time to time. As we walk back to the minibus for the ride home, past the trinket stands selling 'authentic Batak art objects' and printed souvenir T-shirts, Ndapet shakes his head, seeming a little embarrassed about appearing in the street of the tourist resort wearing the traditional cloth, but pleased nonetheless. 'Getting well, that's what's important," he says.

\section{SEVERING THE BONDS OF LOVE}

On the way back to Padang Bulan, the topic of conversaion in the minibus is what the mediums have seen at the lake. Comparing their experience, the mediums construct a story about what has happened to Ndapet's tendi. They all saw the beautiful young woman with long hair who accompanied Ndapet's soul. She was-by herself! they exclaim-paddling a canoe across the rough waters of Lake Toba from the island of Samosir. So beautiful, she must have been a princess. And she was accompanied by her pets, a white swan and a great fish. Had I seen them? they ask me. Even with ordinary vision, anyone could have seen the fish, black beneath the water, they say, and the swan flying above.

Nande Randal takes these elements and, with Nande Sila and Nande Harta chiming in, weaves an explanation around them. The girl, she says, is indeed a princess, the daughter of a powerful Toba Batak keramat spirit of Samosir Island. She is brave and independent, for she dared to steer a dugout canoe all the way across the lake by herself. With hair reaching to the ground, and her devoted pet fish and swan, she is a miraculous figure, an admirable girl-spirit, they all agree. What happened to Ndapet's soul was this: when he was frightened by the near-accident along the road to Prapat, his tendi did escape. And it was captured by the long-haired girl spirit. This is why, Nande Randal explains, the soul could not return; it was imprisoned on the island of Samosir. The girl was fond of Ndapet's tendi, but her parents would not allow her to 'marry' the boy's soul, since Ndapet was not a Toba Batak. Willfully, she hid the tendi away so that her parents would not know that she had kept it, and would occasionally take it out to play with. That she meant no harm to Ndapet was clear, since he was not really sick. The pains he suffered at times were the result of her tying up the tendi so that it would not escape while they were at play.

When we came to the site of the disappearance of Ndapet's soul, Nande Randal called her spirit-helpers to negotiate the soul's release with the keramat spirits of the area. They informed the girl-spirit's father of their purpose, and when he learned that his daughter had kept the soul that he had told her to release, he ordered her to free it. She was to receive the white chicken in its place. The girl-spirit acquiesced to her father's demands, and, because of her fondness for the tendi, she accompanied it across the lake for a last farewell.

This narrative, as Nande Randal tells it, seems to have no point of contact with Ndapet's own life, except for the coincidental one of having passed along this road and been frightened in this particular place (or one like it) some 10 years before. The story is wrapped around Ndapet's experience as the Toba cloth is wrapped around his shoulders, and its seems that neither the cloth nor the narrative really touch him. Ndapet himself shows little interest in the 
narrative; he has indeed remained relatively passive throughout the day's proceedings. But his participation is not necessary; it is enough that he allows the story to be produced, as he allows the ceremony to be performed. The story, with its potential for transforming the diffuse experience of illness into an object of nostalgic contemplation, is simply there for him to reflect on.

The narrative constructed for Ndapet by Nande Randal and his mother is entirely in keeping with Prapat's reputation as a place of romantic liaisons and runaway lovers. Though its actors are drawn from the Arisan's supernatural pantheon, the story is located solidly in an idiom defined by the fantasy images of commercial teen films and pop novelsstar-crossed young love, parental pressures and prejudices, even the willfully modern and independent young girl who plays the leading role in the drama. The narrative makes sense of Ndapet's illness, for him and for his elders, by casting it in this familiar idiom, while it also makes sense of the Arisan's 'oldfashioned' beliefs for the Christian young man by presenting them in these standard images of 'up-todate' youth culture. It does this in a gentle way which does not to any great extent compromise Ndapet's own religious beliefs. The narrative is complete and self-contained, located in a trivial incident distant in space and time from Ndapet's everyday life and in a moment of concluding through which, as both Ndapet and the girl-spirit of Samosir accept the wisdom of parental authority, the bonds of love which join the two are severed. Because it makes no further demands on him, the narrative allows Ndapet to turn away from the spirits as he turns away from his illness. The narrative thus creates a mutual understanding across the gap of difference, while allowing that gap to remain, as it must, intact.

\section{MORAL OBJECTS AND REPRESENTATIONS OF KINSHIP}

To one who has attended other Karo ceremonies, or experienced the pervasiveness of kin ties in the ordering of everday social life, what is striking about the mulahi kahul ritual and the activities that surround it is the near-total absence of kinship in the organization and execution of ritual action. It is not, for example, the anak beru who prepare the pangir hairwashing liquid, but rather Nande Harta's Arisan comrades. The hairwashing itself is carried out, not by the anak beru, but by each participant individually. No special deference is offered to the present kalimbubu; in fact, kin relations between the sponsors and the other participants are not marked in any way. One cannot tell by observing their actions who is Ndapet's kalimbubu and who his anak beru. Representatives of the kalimbubu and anak beru-Ndapet's teenage cousins-are present, it is true, but they have no role in the performance. It is as if they are only there so that Nande Randal can announce their presence to the spirits in her invocation. Kinship is still a component of ritual action, but it is present in a symbolic form, as simply another item in the ritual 'catalog'. This is a far cry indeed from what one would ordinarily describe as adat $k u h$.
This transformation of kinship from structuring principle to symbolic representation will be even clearer in the spirit possession ceremony held upon our return to Padang Bulan to complete Ndapet's ritual therapy. Like all major Karo ceremonies, this begins with the dancing of the various kin groups, each in turn making their presence visible, acknowledging their desire to support the ceremony's purposes, and enacting, through their dancing, their particular relationship to the ceremony's sponsors. But here, at Nande Harta's ceremony-and this is true of all the Arisan ceremonies I attended-it is not in fact the sponsor's kin who dance. Instead, as the musicians announce the turns of the various kin groups- - And now the kalimbubu dance,"' This time the anak beru," "Now the sponsor's clan-mates," and so on it is the members of the Arisan who dance repeatedly, acting out, each time, the proper attitude of respect, deference, blessing or mutuality for each kin category, through their movement to the orchestra's music. Whether or not the sponsor's kinspeople are in fact present, it is the Arisan members themselves who dance, replacing, in symbolic representation, the participation of actual kin with a dramatization of kinship in the abstract.

This is in part a practical solution to the dilemma of Arisan members, and other followers of Pemena/ Hindu, who sponsor rituals of 'belief' (as opposed to the secular 'adat' rituals such as weddings and funerals) in which their Christian kin are not willing to take part. By reducing kinship in this way from the structure of relationships that order ritual action to a self-contained symbolic representation, the Arisan both preserves the idea of kinship in ritual representation and, at the same time, preserves ritual action from the restrictions imposed by the obligations and demands of actual relations with kin. There are, however, several further consequences of this symbolic containment of kinship.

By separating the idea of kinship from the actuality of particular kin relations, ritual action becomes less bound up in everyday social life. Ritual thus becomes a sort of semi-autonomous arena for symbolic action, rather than a fully implicated arena of social action. The continuity, in other words, between ritual acts and actions in the everyday world is severed.

Set within this now semi-autonomous zone of ritual and contained in its idealized representation, kinship becomes 'manageable' in symbolic terms. Through the symbolic enactment in dance of the kin groups' presence and affirmation the ritual's purpose is validated, as it should be, by kalimbubu, anak beru, and senina (clan-mates)-whether Nande Harta's actual kin would approve of it or not. Controlled rather than controlling, kinship becomes, in the ceremonial context, just what one would ideally wish it to be-a harmonious expression of group solidarity. At the same time, however, this containment of kinship in a semi-autonomous symbolic form, embedded in the larger semi-autonomous sphere of the ceremony, limits the potential of ritual to effect the social reality that it (ideally) represents. This in turn has both a positive and a negative side. Ritual may not greatly disturb kin relations, but neither can it solidify them. For the Arisan members, the former advantage may far outweigh the latter disadvantage. 
Finally, the effect of this containment of kinship upon the ritual form itself must be considered. With the loss of the structuring principle of kinship, the various elements of ritual are freed to become semiautonomous objects in their own right, objects whose significance lies simply in their presence or absence within the ritual zone. It is the fragmentation of ritual action which informs Nande Harta's (and the Arisan's) approach to adat $k u h$, full adat. Where adat $k u h$ was once a pattern in and through which all the various kin groups, as well as the ancestral and territorial spirits, enacted their reciprocal rights and obligations, it is now a 'list' of necessary ritual items. If all these objects-of which kinship is one, along with the fine white cock, the offering of fruit and flowers, the brightly colored packets of rice, and the little green and pink flags-are in place and perfect, then the adat is complete. Yet their meaning has, in a significant way, changed in the process of transforming adat from overarching pattern to shopping list. For the various elements of ritual are now no longer justified by the bonds they create, by their interrelation with other elements in a larger whole, but rather by intrinsic moral qualities within the objects themselves. Thus the Arisan members explain the giving of betel to the spirits not in terms of establishing and affirming ties of mutual trust (for the betel quid may be the vehicle for poison and sorcery as well as a pleasurable gift), but as a sign of respect due to the intrinsic 'goodness' of the betel plant. Offerings of rice, salt and eggs presented to the musicians who perform at Arisan ceremonies are similarly explained as tokens of respect, rather than as objects whose giving, and receiving, binds the musicians--and their instruments-into the total pattern of adat. Likewise, the fragrant citron (rimo mungkur) is said by Arisan members to be used in the pangir hairwashing liquid because of its essential 'goodness', its purifying and cleansing properties which prepare a person to become an appropriate vessel for the 'clean' keramat spirits. In contrast to this interpretation, the rimo mungkur appears in myth as the mediator par excellence between the sky-world of the spirits and the human middle-world, and it is characterized (by other, nonArisan curers) as being of an intrinsically mutable nature, which allows it to convey whatever properties - good or evil-that its possessor wishes [32].

The clearest example of the Arisan's urge to replace mediation with morality appears in the interpretation offered for the use of a red, a white, and a yellow chicken in the ritual meal (tambul) given to the various spirits that take part in the possession ceremony. According to the traditional interpretation of the tambul, the significance of the three chickens lies in their embodiment of particular kinship relations. The white chicken must be donated by the sponsor's clan-mates, as a representation of the 'white blood' (i.e. semen) that joins members of the descent group; the red chicken is given by the sponsor's anak beru, an acknowledgement of their utang man kalimbubuna, their irredeemable debt to their wife-givers for the red 'female' blood of birth; and the yellow chicken, a representation of the continued blessing which bestows wealth and good fortune (in the form of gold coins and the ripening, golden rice) is contributed by the sponsor's kalimbubu. This complex set of prestations, in which the gift both moves along the lines of kinship relations and at the same time serves as a material representation of those relations, is reduced by the Arisan members to a simple commercial transaction, in which Nande Harta - in this casepurchases the necessary chickens in the market. The significance of the red, white and yellow chickens is explained through a series of simple moral equations: white equals purity, so it is the appropriate food of the pure, 'clean'keramat spirits: red equals anger and violence, so the red chicken serves for the aggressive war-chief spirits; and the yellow chicken, which remains an inexplicable choice selected because 'that's the adat', falls by default to the less-important (and morally ambiguous, from the Arisan's perspective) family spirits.

This production of self-contained moral objects is characteristic of the Arisan's ritual and therapeutic endeavors. Just as Nande Randal and Nande Harta construct a romantic narrative around Ndapet's illness that serves to tranform the diffuse experience of suffering into an object of nostalgic contemplation, so the entire thrust of the Arisan's ritual activities lies in this same direction: breaking apart the flow of experience into its component parts, which are, in the process, made manageable and comprehensible. By shattering the total pattern of adat (and social life) into semi-autonomous fragments, the Arisan is attempting to come to terms, not just with a fragmented social world, but also with the necessity of that process of fragmentation.

This is not, of course, the whole story. Networks of social relations, built upon affection as well as obligation and customs, are not so easily reduced and contained, nor is experience always so manageable. So there is a counter-thrust present in ritual as well, in which relations between people, objects, and groups are reasserted, and where the bounds that define the semi-autonomous objects of ritual begin to break down.

\section{SORCERERS AND FAMILY SPIRITS AT THE 'GRANDPARENTS' CEREMONY}

When the kahul chicken was freed at Prapat, the bonds restraining Ndapet's soul were also severed. But there was still a final move in his therapy, and this took place in the context of the spirit possession ceremony held upon our return to Padang Bulan. There, however, the focus was not so much upon Ndapet's illness and the meaning it held for him and for his family, but rather upon the more general meaning of illness and misfortune-and, of course, of success-for the group as a whole. The mulahi kahul ceremony produced at least a potential mediation of difference in the narrative which both contained and explained Ndapet's illness. But the subsequent spirit possession ceremony, equally aimed at creating an explanatory bridging of difference, was less successful in this endeavor-for reasons intrinsic to the logic of the Arisan's therapeutic idiom and to the tension between this idiom and the wider field of social discourse in which it is located. This tension is manifested in the disruptive presence of sorcery and family spirits in the ceremony. 
These spirit possesion ceremonies, called kerja nini, 'grandparents' ceremonies' (nini, 'grandparent' being the proper term of respectful address for spirits), are the centerpiece of the Arisan's ritual activities. Whether its purpose is to treat an illness, or to initiate a new spirit medium, to 'close' a cycle of misfortune or to 'open' a new house, or simply to thank the spirits for their past favors, the ceremony follows a single basic pattern, to which added elements may be grafted according to the ritual's goals (and the sponsor's financial circumstances). Thus, in the case of Nande Harta's ceremony, a brief soul-calling (ndilo tendi) rite, which featured some exquisite dancing by Nande Randal, was tacked onto the end of the first night's activities, to ensure that Ndapet's tendi indeed found its way home from distant Prapat.

Whatever its ostensible aim, the kerja nini is held to honor the keramat spirits, who are the source of all well-being and success. The ceremony opens with the obligatory dancing of the 'kin' groups, followed by a brief appearance of the household guardian spirits (begu jabu). Then the mediums begin a dance of invitation, entreating the keramat spirits to descend and 'alight on' their hosts. Through the vehicle of the chosen host's body, the spirits may then enjoy the entertainments that have been provided for them: music, dance and merrymaking; offerings of food, drink, tobacco and betel; and gifts of incense, cologne, clothing, jewelery and other desirable items. Once the spirits have been so feted, they are begged to continue to bless all the participants, or to intervene to improve the circumstances of the sponsoring family.

During the course of a ceremony-which may last as long as 2 days and involve upwards of 100 participants and spectators crammed into the sponsor's sweltering, crowded living quarters-a variety of spirits are called down. The spirits tend most often to arrive in generic groups, rather than individually. Thus, one might observe a group of trance-dancers all possessed by 'war-chief' spirits or 'ladies-in-waiting', or 'mothers'. After a group has been sufficiently entertained they all depart, bestowing their blessings on the crowd. Then, once the dancers and musicians take a brief rest and perhaps drink a glass of tea, the music begins again and another group of spirits descends.

Keramat spirits are rarely distinguished except by these generic types, of which there are a rather limited number. The sequence of spirit-appearances is likewise relatively fixed. As a result, Arisan ceremonies are more or less standardized and predictable, with little variation from one to the next in either form or content. There is, however, some room for performative improvisation. The most exciting moments in the cercmonies-when spectator involvement and interest is at its height-are the sudden appearances of 'uninvited' idiosyncratic spirits who disrupt the orderly routine of the ceremony. These disruptive spirits are usually, but not always, family spirits who come to complain of neglect by their human kin.

In the past, relations between spirits and humans, like all social relations, were contained within the structure of kinship. Rites of propitiation and supplication were addressed primarily to the ancestral spirits-of close genealogical kin (begu jabu) for a household, or of lineage founders and territorial guardians (pajuh-pajuhen kuta) associated with the ruling lineage for a village or village ward. These, however, are today virtually unrepresented in the Arisan's pantheon. Instead, it is the keramat spirits of wild, uninhabited regions who are of most concern. Arisan members offer two defining characteristics of the keramat. The first of these characteristics is the absence of kin ties, either real or fictive, linking them to humans, and the second is their intrinsic moral quality: they are pure, clean, and good. It is through an abstract moral code, and not through the ties of kinship, that relations between keramat spirits and humans are formed and maintained-through, one might say, a moral contract established between keramat spirit and human host. As long as the host obeys the moral rules and obligations set forth in this 'contract', the spirits will bestow their blessings; should the host not honor the agreement, neither will the spirits.

Still, the bonds of kinship are not so easily broken. Although one of the moral demands of the keramat spirits is that dealings with the begu jabu and other family spirits be limited, this same moral code demands also a certain respect for these spirits of the family, as an expression of adat, just as respect for living kinspeople is also essential. The family spirits are still present at Arisan ceremonies; they receive their own gift of food, the 'value-free' yellow chicken described above, and they have their own place in the ceremonial action. But it is a restricted place, like the contained space of kinship in its obligatory enactment in dance. The family spirits appear for a moment, receive their meal as a token of respect, and depart-all before the main action beings. However, since these spirits are joined to their living kin not by ties of moral regulation but by the intractable bonds of kinship, custom and affection, they are not so containable - and they obstinately make their presence known, and their words heard, in other places as well.

So it was at Nande Harta's ceremony that as the second day's activities began and the mediums danced, inviting the group of 'mother' spirits to descend, Nande Randal was suddenly and-she later said-inexplicably possessed by a male spirit whom the other mediums did not at first recognize. Another of the mediums was also possessed, by an angry, garrulous female spirit. In the ensuing confusion it finally became clear that they were the spirits of Bapa Harta's father's brother-the famous curer known as Sibayak Berastagi-and his wife, Nini Biring. The other dancers quickly called for Bapa Harta (who was asleep in the back of the house) because, they said, they didn't know these spirits or where they came from.

Bapa Harta reluctantly and with much grumbling came forward to talk to the two family spirits, and Nini Biring immediately began to upbraid him for his behavior. "Don't use that streetcorner language here," she sputtered at him. "When you meet us, you shouldn't act like that. Next time, don't say you didn't know better." She went on to ask why Bapa Harta's kinspeople hadn't been invited to the ceremony, and he tried to excuse their absence by saying that some of them were too far away. "They"re too 
far away, that's what you say. Don't you forget your family birthplace!" she retorted. "Times have changed," Bapa Harta replied, "and things are far different now." "Well, then," Nini Biring shot back, "you've got a big problem" [33].

After a few minutes of this repartee, as a crowd of spectators gathered, joining in the debate, Sibayak Berastagi requested that the orchestra play the song of blessing 'Simelungun Raja', and he began to dance while offering advice, speaking slowly and sonorously: "Don't forget the old ways, the village guardian spirits, the household spirits and all the spirits of your village.... Don't forget your kalimbubu in the village. Then we'll all remain with you. ... Don't just half-believe. Then good fortune will continue always."

Breaking in loudly, Bapa Harta complained, "But the village guardian spirits, they can't be propitiated any more [la nai terpajuh]." Everyone began to talk at once, repeating the Sibayak's words and arguing about the proper way to deal with Bapa Harta's disrespectful attitude. Finally, with various disputes ranging around the group, Sibayak Berastagi cut in, "It's like this. I've come to your house in the morning. I'll say to you all, let's not disagree with one another. Those of this house, let's not disagree with one another. You too, all of the five clans, let us make our speech as one, let us not hold bad opinions of one another." At this point the crowd became really unruly, shouting and crowding around. Ndapet's clder brother Harta shouted, 'That's the thing to do! Stay with us always!"

A few minutes later, Sibayak Berastagi departed. Nini Biring, however, stayed behind to joke a bit more with the rowdy young men, telling them that if they didn't paint her grave monument nicely she'd give them a swift kick. "Once I get mad, I really get mad," she threatened.

Nande Harta had also gone into trance and was possessed by one of the keramat spirits. Through the excitement caused by Sibayak Berastagi's abrupt appearance and equally abrupt departure she remained quiet. After he had left, however, the keramat chastised the mediums for not showing the Sibayak the respect he deserved. They had failed to offer him any food. The problem was, they responded, there had been nothing to offer him, for the yellow chicken of the family spirits had already been eaten the evening before. There was a chicken remaining, a white chicken that had not yet been served, but it was 'not his food'. The keramat responded sharply, "If your ceremony doesn't succeed, don't blame others. You have to flatter your family spirits before we keramats can come to the house.... You all don't know anything." The chastened mediums accepted his reprimand and agreed to do better next time [34].

That they would in fact 'do better next time' is doubtful. This same scenario of complaint, failure, reprimand and contrition was repeated at virtually every Arisan ceremony I attended, with no apparent effort exerted to remedy the problem. Perhaps, as Bapa Harta honestly asserted, there is no remedy, since the times have changed, kinspeople are "too far away', both geographically and philosophically, and the guardian spirits, both of the household and of the village, can indeed no longer be propitiated due to Christian disapproval. One could say that this expression of the continually unmet demands of the family spirits in Arisan ceremonies is simply another symbolic containment of a dilemma too large to be resolved. The 'unexpected' appearance of the family spirits would then appear not as a disturbance of the ritual order, but rather as another element built into the ritual form. Yet the problem that these spirits pose goes far deeper than that, for their presence is not only a reproach to their living kin, but also to the fragmentation of social relations into 'moral objects'. The nostalgic image of the past which the family spirits present-of social relations joining all members of society into a seamless and harmonious wholesuggests both that the bonds of kinship are not so easily severed and that it is indeed in those bonds that the true and proper basis of social action lies.

But the intrusion of the family spirits is not only such predictable 'disruption' in Arisan ceremonies. Sorcery attacks are another unvarying component of ceremonial actions. The potential disruptiveness of sorcery is, however, much greater, for the sorcerer may interfere with the mediums' ability to go into trance or cause them to be possessed not by the benevolent keramats, but by violent evil spirits.

Nande Randal described one ceremony that was ruined in this way by sorcery. Twenty people were simultaneously possessed by these evil spirits, she said, and, with the help of her 'war chief' spirit, she and onc of the other mediums began to do battle with them. Everyone was rolling on the floor, she recalled, and finally the performance ended in confusion when the woman who had sponsored the ceremony struck her head on the large bamboo tube zither (one of the instruments in the orchestra) and had to be taken to the doctor to stop the bleeding. The sorcerer? It was the Arisan's Bapa Jempol, the husband of the rich senior medium Nande Jarum whom Nande Harta so disliked. Nande Jarum claims that the others are out to ensorcel her, said Nande Randal, then added rhetorically, "but isn't she really the one who keeps them (i.e. the evil spirits)?" Had all the keramat spirits not been present at Nande Harta's ceremony, Nande Randal asserted, the same thing would have happened there.

At Nande Harta's ceremony, the attack of evil spirits occurred during the first night's activities as the second group of keramat spirits was called down. Realizing that sorcery was at work, Nande Randal, along with another of the mediums and a male spectator-one of Nande Harta's former patients-fought off the attacking spirits and then stood guard while the other spirits in the group were served their food. "That's why I didn't eat with them," said Nande Randal. "I was afraid of being hit by the sorcery."

Fortunately, the spirits were successful in warding off the danger. And this time, who was responsible? Nande Randal would not say, since nothing had come of the attack. But it was someone present, she hinted, one of the Arisan members. "That's how it is," she explained, "if we're all talking about one another all the time, well, can't you expect them to 'try' one another too?" Now you know what they're like, she said to me. "That's why you need protection, 
why I always make the magic signs to protect myself. 'Auntie, auntie,' they all say to me, and I pretend they're all fine. After all, I cured them all, I taught them all. But now you can't say you don't know about them."

Both the complaints of the family spirits and the aggression of the sorcerer undermine the logical coherence of the Arisan's moral order. But they do so in opposed ways. If the family spirits appear as a denial of the fragmentation of older unities into semi-autonomous objects, then sorcery pushes that fragmentation to its logical extremity. An expression of the triumph of pure individual self-interest over all social relations, sorcery exposes the falsity of any moral justification of that fragmentation. Objects and actions are not, in and of themselves, intrinsically good or evil; rather their value depends upon the interpreter's perspective. And this is what sorcery reveals, as it moves along the pathway of success and envy simultaneously towards and out from the individual who is at once sorcerer and victim. Though Nande Jarum claims she is the victim of sorcery, the others know her for the one who keeps the evil spirits. Her success is, for them, evidence of her wickedness, while for her it is the proof of her good intentions.

The kerja nini aims at producing a semiautonomous zone for the enactment of the Arisan's moral vision. This vision attempts to mediate the idealized past of 'tradition' as the Arisan sees it and the commoditized present in which thcy live, through the joining of spirits and success into a moral whole. But the intrusive family spirits present another (and equally idealized) vision of tradition as kinship and community, just as the sorcerer presents another vision of success in the form of aggressive self-interest. Together, they do more than contradict one another. In their jaggedly antagonistic stances, they also reveal the hopelessness of the mediating endeavor. And, at the same time, they draw the self-contained sphere of ritual back into the problematic and conflictive world of social and commodity relations.

Hanging without a rope, set down without a resting place. This is how one curer described the position of the contemporary spirit mediums to me, using a traditional Karo metaphor of out-of-placeness. They are able to locate themselves neither in the past nor in the present, nor are they able to accommodate the contradictory values of the two. For the Arisan members, their ritual practice does more than reflect this feeling of homelessness in a world beyond their control. It also, in a very real way, produces that homelessness, as it glances off the dominant vision of their actions as primitive, pagan, satanic-and blatantly, self-interestedly commercial. It is this sense of out-of-placeness which, clothed in the moral form of another semi-autonomous object, is represented by that paradoxical source of all well-being, the keramat- the pure, clean, and kin-free inhabitant of the wasteland beyond human habitation.

And Ndapet? Can that voice of out-of-placeness offer him any comfort? For him, the whole point of his exercise is getting well, by whatever means. When I spoke to him 2 weeks after the ceremony, he was still uncertain about its results. He thought that he felt a little better, but seemed no more convinced of the validity of what had gone on than he had before the ceremony. For Ndapet, it is not that belief somehow, magically, produces a cure, but rather that the cure may produce belief. And this is the problem. For while he has a stake in getting better, he equally has a stake in not getting better, for a cure would require more than an illusory understanding across differences: it would demand an active engagement with those differences, and not just in the self-contained arena of ritual. So Ndapet remains in tension between belief and unbelief, an uncertain witness to the actions performed on his behalf by those who sought his understanding.

For Nande Randal, the officiating medium, the ceremony's outcome is both more certain and less momentous. After 2 days of vigorous activity in the ritual, she told me, the rheumatism that had bothered her for years suddenly disappeared. That, she said, is the gift of the keramat spirits. But their gifts are not unilateral; they demand returns as well, and if these are not given the temporary gains achieved with their help may become an ultimate loss. And so Nande Randal told her own story of spirits and success. When she was younger, she said, the spirits blessed her and she became wealthy from her curing activities and always offered them gifts in return. But her children had wasted all her money and now she could no longer provide the offerings that the spirits were demanding. She had begun a slide into poverty, to the tiny ragged farm outside Padang Bulan where she now lived, behind the Chinese graveyard that frightened off her potential patients. The spirits rarely spoke to her these days. And now her children, who had squandered her wealth, were themselves demanding that she become a Christian, that she give up the ways of the keramat spirits and become 'respectable'. She would join the church someday, she said, when the spirits finally deserted her, when the success was finally and irretrievabiy gone. When her conversations with the spirits had ended. That, she concluded philosophically, was the way things went.

\section{CONCLUSION: EFFICACY, INTEGRATION AND 'DOING IT RIGHT'}

Behind all the assumptions of what I have called the 'integrative model' of anthropological analysis of healing practices lies an ambivalent belief in the efficacy of the cure. Curing practices must, we believe, cure something, or else why would they continue to be performed? If this therapeutic efficacy is not bio-medical in nature, and if we deny the reality and the healing power of the spirits, then this efficacy must be located elsewhere. And so, in seeking this locus of therapeutic efficacy, we turn to concepts of integration and coherence. Thus, ceremonial curing is effective, it might be argued, because it produces social solidarity, reinforces a generally held belief system, or gives coherence to the essentially disorderly personal experience of illness-as if the "naming' of an illness in itself somehow makes suffering more tolerable. Alternatively, though this amounts to very much the same thing, the curing ritual can be seen as efficacious and integrative in its provision of a socially approved, restricted arena for 
the expression of otherwise disruptive, disorderly behaviors and ideas-a kind of 'acting out', for the individual and for the group.

Yet, as I watched and took part in Nande Harta's ceremony-as I had many other, similar performances-I began to wonder if these views might not be misdirected: if, in seeking for order, efficacy, integration and coherence, we might be missing more important ways in which curing ritual may be disintegrative, incoherent and, perhaps, dysfunctional [35]. And if, at the same time, we might be missing the crucial significance of this 'disorderliness' [36].

Concepts such as 'integration', 'coherence' and 'efficacy' can shed little light on the Arisan's curing practices. The unifying social mechanisms do not work here-for the society as a whole, or the Arisan itself, or even for the family; indeed, the curing ceremony seems to be actually disruptive insofar as it pushes for further fragmenting of already tenuous social bonds, as it forces a confrontation between conflicting world views, individual interests and interpretations of value. This is a confrontation which is not limited to the self-contained sphere of ritual but which resounds throughout the web of social relations that make up everday life as well. The confrontational dimension of these curing ceremonies likewise undercuts any effort towards producing a coherent view of illness and therapy by generating a multiplicity of contradictory and mutually undermining meanings. If there can be said to be a shared 'cultural idiom' of illness here, it is sorcery, and it is precisely this cultural idiom that the ceremony attempts-unsuccessfully-to deny, for the full recognition of sorcery at work would be more disruptive still, within the Arisan as well as in its relation to the dominant Christian community. Even the analytical last resort of 'acting out' has little explanatory power in this case, at least in terms of the patient, for Ndapet himself seems to take little part, and have even less interest, in the performance. What can we say about a curing act in which the curer recovers but the patient does not?

Of course, there is some minimal expectation of efficacy among the participants at the Arisan's ceremonies. Ndapet, at least, wants to get well. And there is some effort towards integration as well. The narrative constructed around Ndapet's illness aims at making two different world views mutually intelligible, if not unified, thereby producing a kind of tolerance that can. in the absence of some ultimate integration, at least pass for it. There is in the kerja nini spirit possession ceremony also a (perhaps nostalgic) desire for social integration and unity, though the ceremony equally acknowledges-indeed, builds upon-the real impossibility of achieving that desire. Yet, given the apparent failure of the ceremony to achieve either therapeutic efficacy or social and cultural integration, to assign analytical priority to these would be to miss the point. It would be to relegate the Arisan's efforts to some residual category according to its failure to meet our analytic standards, to view it as a 'survival' of earlier, more efficacious cultural practices, or as a degenerate form of those practices in the service of commercial ends. It would be, in other words, to adopt a view dangerously close to that of Christian Karo who accuse the Arisan members of being 'backward', commercially motivated, at best misguided and at worst sorcerous. While perhaps none of these evaluations is entirely baseless, there is certainly more to the Arisan's activities than that.

I would suggest that the whole line of reasoning described here is off the mark, and that another way of viewing the Arisan's curing practices should be sought. In this essay I have suggested one such alternative and, rather than focusing on efficacy and integration, examined some of the particular sets of social and cultural tensions which resonate through the ceremony and which, at the same time, the ceremony seeks to contain. This is not, it should be stressed, simply to present the Arisan's curing practice as a symbolic resolution of those tensions, for, as should be clear by now. matters are more complex than that.

There are a multitude of voices in the ceremonyof spirits and of humans, all putting forth their own particular points of view-but over and through them runs the hum of the dominant social discourse. This discourse, at least insofar as it concerns the Arisan's practices, is largely couched in terms and categories put forth by the 'progressive' Christian community, who have taken on the position of arbiters or definers of both tradition and morality. Others, from their various stances, may dispute or harmonize with that discourse, but they do so largely in a language that it has created, in its terms. This is true even of the spirits. How, then, to turn that language against itself? How to use its own terms to deny the conclusions that it reaches, the interpretations that it makes? This is the dilemma that the Arisan faces as it attempts to find its own space within the discursive field, a space defined precisely as 'out-ofplaceness'.

I have suggesed above that the keramat spirits are a representation of the out-of-placeness which is, for Arisan members, their 'place' in society. They are, as much as the other moral objects of the Arisan's practice, a produce of the process which Fredric Jameson, in the passage quoted at the beginning of this essay, describes as reification or rationalization, in which traditional social and cultural unities are broken down into a variety of now autonomized fragments which acquire, at the same time, a life of their own. To complete here that quotation, Jameson goes on to say that in that process
these now isolated broken bits and pices of the older unities acquire a certain autonomy of their own, a semi-autonomous coherence which, not merely a reflex of capitalist reification and rational- ization, also in some measure serves to compensate for the dehumanization of experience reification brings with it, and to rectify the otherwise intolerable effects of the new process [10].

And this is precisely what-though certainly in a more practical, down-to-earth (and, to be sure, mystified) way than the aesthetic acts that Jameson is primarily concerned with-the keramat spirits do. Not just a reflection of that process of social and psychic fragmentation, they are also the means of harnessing the 'out-of-placeness' of Arisan members, a very literal 'fetishizing' of alienation itself which then become a tool in the struggle against the hurtful 
effects of that alienation, for curer as well as for patient.

The two, patient and curer, are in a sense inseparable. It is through illness that a spirit medium achieves the ability to cure. The presence of a keramat spirit is first manifested in illness, in episodes of madness, misfortune and suffering. It is through the acknowledgment of the spirit's presence and its demands, and the subsequent establishment of a moral pact between host and spirit, that the new medium gains her ability to cure. The medium, in this process, is by no means 'cured' herself; rather, the suffering she has experienced takes on a new, productive form. At the same time, she is both accepting her out-of-placeness and, one might say, establishing a pact with it, too. For it is through the acceptance of the role of spirit medium, through the formalizing of the moral relationship with the spirits who guide her, that her assignment to the place of out-of-placeness is completed. From this, and from her use of the power thus gained to cure others, she may achieve material success, a success that makes her position tolerable on one hand, and possible on the other.

The delicacy of this position can be seen in the predicament of the old medium Nande Randal who, as success inexorably fades, is drawn out of the keramats' world and into the Christian 'respectability' that her children desire. It can also be seen in the conflicting swirl of sorcery accusations that surround Nande Jarum, the rich senior medium trapped in the webs of envy and suspicion which her success has created. And it is also the delicacy of this position that is addressed by Nande Harta's concern to 'do it right' this time, to produce a perfect enclosed arena in which the keramat spirits can act, untouched by the demands of either the past or the present-a perfection which is, of course, never quite achieved.

For Ndapet, however, it is precisely this failure to achieve perfection that allows him to maintain his own delicate position-his own tenuous balance between belief and unbelief -which, in the absence of a true cultural coherence and unity, of a true 'cure' in the fullest sense of the word, may pass for such. From his own side of the gap of difference, Ndapet can look across at the world of the spirits-and then turn away.

Acknowledgements - This essay is based on research carried out in Medan and Kabupaten Karo, North Sumatra, Indonesia, from February 1983 to December 1985 under the auspices of the Lembaga Ilmu Pengetahuan Indonesia. This research was supported by grants from the Fulbright-Hays Doctoral Research Abroad Program, the Social Science Research Council and the American Council of Learned Societies, and from the Rackham Graduate School of the University of Michigan. I received helpful comments on various drafts of this paper from Les Adler and Sherry Ortner, as well as from the editors of the volume, Carol Laderman and Penny Van Esterik. The insightful comments and criticisms of this journal's anonymous reviewers were both interesting and useful. I would like to thank all of these persons. The conclusions, opinions and other statements in this publication are those of the author and not necessarily those of agencies or individuals listed above. More than any others, I have to thank the members of the Arisan of Simpang Meriah for their patience, generosity and general good humor. They helped make my field experience a thoroughly enjoyable one, and I hope I managed to amuse them as well.

\section{REFERENCES}

1. Crapanzano V. The Hamadsha: A Study in Moroccan Ethnopsychiatry. Unjversity of California Press, Berkeley, Calif., 1973.

2. Obeyesekere G. Psychocultural exegesis of a case of spirit possession in Sri Lanka. In Case Studies in Spirit Possession (Edited by Crapanzano V. and Garrison V.), pp. 235-294. Wiley, New York, 1977

3. Spiro M. Burmese Supernaturalism. Prentice-Hall, Englewood Cliffs, N.J., 1967.

4. Morton A. Dawit: competition and integration in an Ethiopian Wuqabi cult group. In Case Studies in Spirit Possession (Edited by Crapanzano V. and Garrison V.), pp. 193-234. Wiley, New York, 1977.

5. Turner V. The Drums of Affliction. Oxford University Press, London, 1968.

6. Davis-Roberts C. Kutambuwa Ugonjuwa: concepts of illness and transformation among the Tabawa of Zaire. Soc. Sci. Med. 15B, 309-316, 1981.

7. Kleinman A. Medicine's symbolic reality. Inquiry 16, 206-213, 1973.

8. Lévi-Strauss C. The effectiveness of symbols. In Structural Anthropology, pp. 186-205. Basic Books. New York, 1963.

9. Obeyesekere $G$. The idiom of demonic possession: a case study. Soc. Sci. Med. 4, 97-111, 1970.

10. Jameson F. The Political Unconscious, p. 63. Cornell University Press, Ithaca, N.Y., 1981.

11. I use the tcrm 'mythic' here in the Lukacsian sense (which should be understood as including, but not being limited to, the strictly 'religious'), which is closely related to the (rather different) uses made of the term by Claude Lévi-Strauss and Roland Barthes. Mythology, in this view, consists in a symbolic resolution of irreconcilable 'terminal points' in thought, through "the reproduction in imagination of the problem in its insolubility" [italics in the original]. Lukacs G. History and Class Consciousness. p. 194. MIT Press, Cambridge, Mass., 1971.

12. Buku Tahunan 1984 Propinsi Sumatera Utara, p. 331. P.T. Saguna Karya Graha, Medan, Indonesia, 1985.

13. Kipp R. The ideology of kinship in Karo Batak ritual, p. 265. Unpublished Ph.D. dissertation, University of Pittsburgh, 1976.

14. For a full description of Karo kinship see Singarimbun M. Kinship, Descent and Alliance Among the Karo Batak. University of California Press, Berkeley, Calif., 1975.

15. The role of kinship in Karo 'secular' ritual is described in detail in [13] Kipp R.; [14] Singarimbun M.; and in Kipp R. The thread of three colors: the ideology of kinship in Karo Batak funerals. In Adat, Ritual and Society in Indonesia (Edited by Bruner E. and Becker J.), Vol. 53, pp. 62-95. Ohio University Papers in International Studies, Southeast Asia Series. 1979.

16. See, e.g. Bruner E. Urbanization and ethnic identity in North Sumatra. Am. Anthrop. 63, 508-521, 1961; Bruner E. Tradition and modernization in Batak society. In Responses to Change (Edited by DeVos G.), pp. 234-252. Van Nostrand, Princeton, N.J., 1976; Means G. Survival of tradition among modernizing Karo Bataks. In Development and Underdevelopment in Southeast Asia (Edited by Means G.), pp. 106-123. Canadian Society for Asian Studies, Ottawa, 1977; Siregar S. R. Adat, Islam and Christiantiy in a Batak Homeland, Vol. 57. Ohio University Papers in International Studies, Southeast Asia Series, 1981.

17. Siregar S. R. A modern Batak horja: innovation in Sipirok adat ceremonial. Indonesia 27, 102-128, 1979. 
18. Data on the religious affiliation of urban Karo are not available; however, figures for the Karo ethnic homeland are as follows: Christian Protestant 35\%; Roman Catholic 12\%; Islam 17\%. The remaining $35 \%$ consists of a few (Chinese) Buddhists, (Indian) Hindus, Pentacostals, Seventh Day Adventists, and the rest (approx. $35 \%$ of the total population) are followers of the traditional religion. (These data do not take into consideration the recent 'Hinduization' of Karo traditional religion to be discussed below.) Though these figures may roughly indicate the pluralistic religious situation of the Karo, it should be noted that Protestant Christianity is considerably stronger, both demographically and culturally, in the city than in the predominantly rural Karo homeland. Buku Tahunan 1984 Propinsi Sumatera Utara [12] p. 227.

19. Intisari Adat Istiadat Karo, Vol. 1, pp. 1-3. C. V. Ulih Saber, Medan, Indonesia.

20. For a discussion of changes in certain aspects of contemporary Karo curing practices, see Steedly M. Innocence as authority: shifting gender roles in Karo curing practice. In Rilual and Socioeconomic Change in the Southeast Asian Periphery (Edited by Russell S.). In preparation.

21. Christian opposition to these activities must, of course be seen in the light of Protestant doctrine regarding the unmediated nature of the relationship between the faithful and the Deity. It should also be noted that this antagonism to 'pagan'practices does not seem to inhibit Christians who fear they have been ensorcelled from seeking the assistance of a spirit medium.

22. The politics of Karo religious pluralism is discussed in greater details in Steedly $M$. Religious tolerance and the image of the pagan past, a paper presented in a panel of 'Constructing and Contesting Tradition: The Politics of Identity in Outer Indonesia, 'SEASSI Conference, 1987. For a general discussion of religion in contemporary Indonesia see Kipp R. and Rodgers S. (Eds) Indonesian Religions in Transition. University of Arizona Press. Tucson. Ariz., 1987.

23. An account of the 'Hinduization' of another indigenous religious system among the Tengger of East Java is given in Hefner R. Hindu Javanese. Princeton University Press, Princeton, N. J., 1985. The early history of the movement which has now become institutionalized as Parisada Hindu Dharma appears in Geertz C. Religious change and social order in Soeharto's Indonesia. Asia 27, 62-84, and in Geertz C. "Internal conversion" in contemporary Bali. In The Interpretation of Cultures, pp. 170-189. Basic Books, New York, 1973. A brief description of Parisada Hindu Dharma in contemporary Bali is given in Boon J. The Anthropological Romance of Bali: 1597-1972, pp. 214-217. Cambridge University Press, 1977.

24. The name 'Simpang Meriah' is a pseudonym, as are the names of all Arisan members that appear in this essay.

25. Most, but by no means all, Karo spirit mediums are women.

26. 'Those in need' includes not only the medium's patients, but also the mediums themselves. In many cases, the keramat's initial attachment to a medium is a result of the spirit's desire to offer a more lucrative profession to the potential host. This of course heightens the contradictory selfless/self-serving nature of the medium's profession. For an example of this see Steedly M. [20]

27. Because it is considered impolite to use the name of one's elders, the Karo practice teknonymy. Thus, the wife and husband whose eldest child was named Imah would be referred to, and addressed as, Nande Imah (Imah's mother) and Bapa Imah (Imah's father) respectively.

28. The most notable of Nande Jarum's misfortunes was the death of two of her patients in a flash flood while she was performing an erpangir $k u$ lau hairwashing ceremony. Other Arisan members took this as the clearest of indications that the keramat spirits were angry at her; she, of course, saw it as an equally clear sign of sorcery being directed against her.

29. For a description of traditional Karo etiological categories and therapeutic practices relating to mental illness, including the category of 'soul loss', see Ginting J. Pandangan tentang gangguan jiwa dan penanggulangannya secara tradisional pada masyarakat Karo. Unpublished thesis (doctorandus), Fakultas Sastra, Universitas Sumatera Utara. Medan, Indonesia, 1986.

30. For a discussion on the kahul offering among the Karo, see Neumann J. H. Een en ander aangaande de Karo-Bataks. Mededeel. Nederlands. Zendelingge. 47, 36I-376.

31. It is possible that these comments on the complexities of Karo adat were stimulated by my presence. However, at the time of Nande Harta's ceremony I had been attending Arisan rituals for well over a year, during which time such a discussion had never before occurred in my presence. It appears that Nande Imah's presence was more significant than the anthropologist's in provoking this discussion. As other Arisan members told me, Nande Imah had been Nande Harta's closest follower and frequent ritual assistant, but this position had recently been taken over by another of the Arisan's junior mediums, and Nande Imah was trying her best to win her way back into Nande Harta's good graces by, among other things, trying to appear as a diligent disciple.

32. As an indication that the moral qualities ascribed to objects such as the betel leaf and the rimo mungkur citron are a recent innovation, it should be noted that these two objects are among the most common and best-known items used in sorcery attacks.

33. One of this paper's anonymous reviewers insightfully suggests that perhaps "there is something therapeutic going on when the usually ridiculing and reluctant father of the patient and husband of one of the officiants gets dragged onstage and upbraided for his forgetting of kinship ties." Certainly this exchange between Bapa Harta and the spirits was the high point of the ceremony in terms of entertainment value, and in that sense could be considered as therapeutic. On the other hand, Bapa Harta gave as good as he got in this exchange and thus the encounter could equally be seen as undermining the ceremony's therapeutic efforts.

34. It should be noted that this criticism of the ceremony as not being 'done right' was articulated through the sponsor herself-the person who was most concerned that everything be done correctly. This type of indirect self-criticism through trance is characteristic of Arisan performances. It should also be noted that, since she was in trance at the time and would likely have no recollection of the spirits' remarks, Nande Harta was the one person who was excluded from the criticism.

35. This same point is made by Geertz $\mathrm{C}$. Ritual and social change: a Javanese example. In The Interpretation of Cultures, pp. 142-169. Basic Books, New York, 1973. Geertz, criticizing functionalist analysis of religion and ritual, states that "the tendency has been consistently to stress the harmonizing, integrating, and psychologically supportive aspects of religious patterns rather than the disruptive, disintegrative, and psychologically disturbing aspects; to demonstrate the manner in which religion preserves social and psychological structure rather than the manner in which it destroys or transforms it" (p. 143).

36. The therapeutic importance of disorder in curing rituals is discussed in Taussig M. Shamanism, Colonialism, and the Wild Man. University of Chicago Press, Chicago, IIl., 1987. During my field work, Taussig [p.c.] encouraged my interest in the disorderly aspects of ritual. 